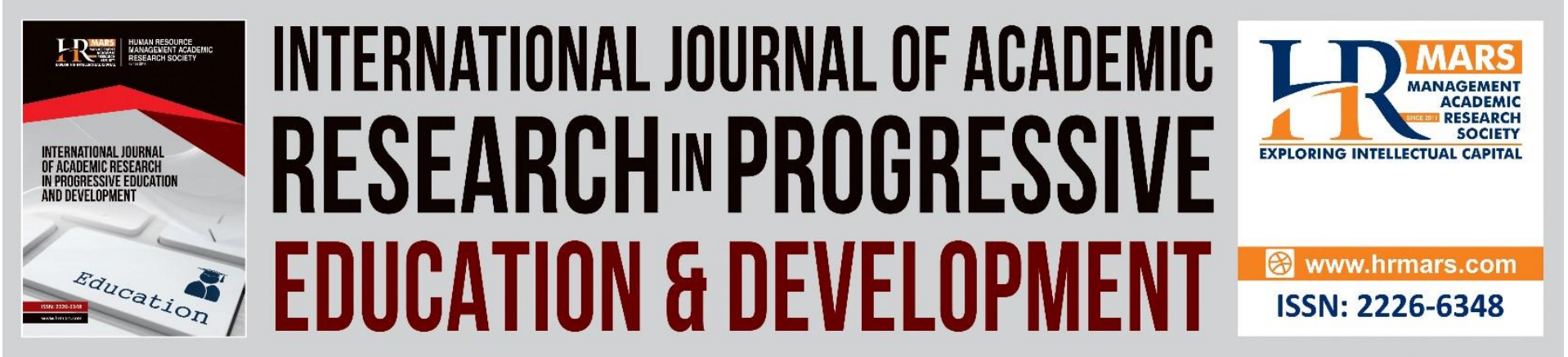

\title{
The Extent to Which Parents of Adolescents in Jordan Use Harmful Mediation Patterns in the Digital World
}

\author{
Nasser Aden Lafi, Roslan Ab Rahman, Nashaat Baioumy, Mustafa Che \\ Omar \& Ab Aziz Sulaiman
}

To Link this Article: http://dx.doi.org/10.6007/IJARPED/v10-i3/11484

DOI:10.6007/IJARPED/v10-i3/11484

Received: 16 July 2021, Revised: 04 August 2021, Accepted: 27 August 2021

Published Online: 19 September 2021

In-Text Citation: (Lafi et al., 2021)

To Cite this Article: Lafi, N. A., Rahman, R. A., Baioumy, N., Omar, M. C., \& Sulaiman, A. A. (2021). The Extent to Which Parents of Adolescents in Jordan Use Harmful Mediation Patterns in the Digital World. International Journal of Academic Research in Progressive Education and Development, 10(3), 1118-1136.

Copyright: @ 2021 The Author(s)

Published by Human Resource Management Academic Research Society (www.hrmars.com)

This article is published under the Creative Commons Attribution (CC BY 4.0) license. Anyone may reproduce, distribute, translate and create derivative works of this article (for both commercial and non-commercial purposes), subject to full attribution to the original publication and authors. The full terms of this license may be seen at: http://creativecommons.org/licences/by/4.0/legalcode

Vol. 10(3) 2021, Pg. 1118 - 1136

http://hrmars.com/index.php/pages/detail/IJARPED

JOURNAL HOMEPAGE

Full Terms \& Conditions of access and use can be found at http://hrmars.com/index.php/pages/detail/publication-ethics 


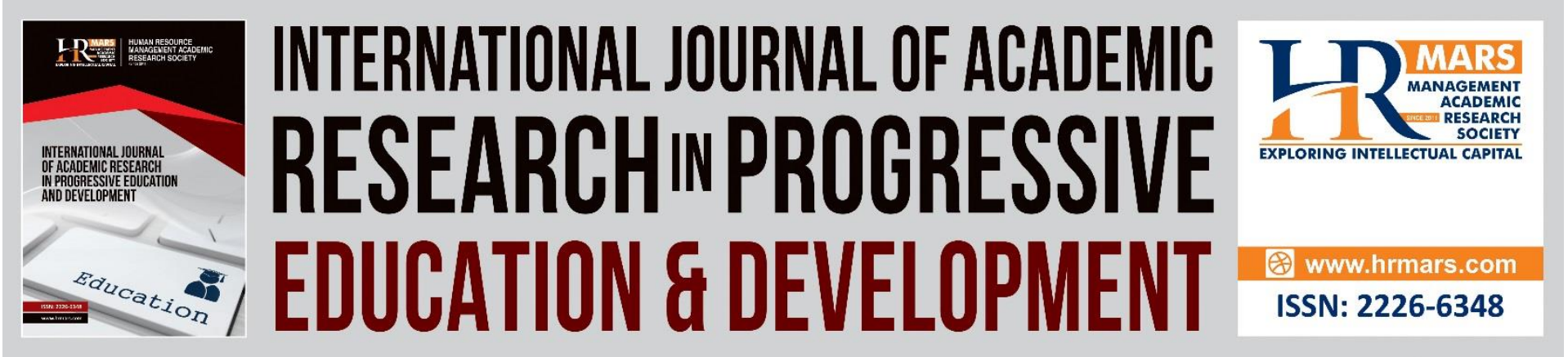

\title{
The Extent to Which Parents of Adolescents in Jordan Use Harmful Mediation Patterns in the Digital World
}

\author{
Nasser Aden Lafi, Roslan Ab Rahman, Nashaat Baioumy, \\ Mustafa Che Omar \& Ab Aziz Sulaiman \\ Faculty of Islamic Contemporary Studies University of Sultan Zainal Abidin, 21300, \\ Terengganu, Malaysia \\ Email: roslanabr@unisza.edu.my
}

\begin{abstract}
Parents have a responsibility to integrate their children into the digital world in a way that enables them to exploit its opportunities and avoid its risks, through the use of regulatory mediation strategies (restrictions, monitoring and direct supervision) or supportive (active, remote, participation), but there are those who pursue methods that are counterproductive or harmful from Through the use of an unstructured management style, complete disregard for children, or complete prevention of contact with the digital world, and the question posed by this study is to what extent parents of adolescents in Jordan use negative (harmful) mediation pasterns in the digital world. The study used the descriptive and analytical approach, through an intentional corean sample of 469 items, through the application of the measure of the use of parents of teenagers in Jordan for harmful mediation patterns in the digital world, the data were processed statistically, depending on the Statistical Package for social sciences. The Results showed that more than half of parents use unregulated mediation or completely ignore their children, and few of them use the method of preventing their children from communicating with the digital world, From the above, it can be concluded that the use of reverse mediation is lesser few, but it does exist and in tangible proportions. Therefore, the study recommends intensifying parenting awareness programs on effective parental mediation patterns and enhancing their media skills so that they, in turn, can help their children safely integrate into the digital world.
\end{abstract}

Keywords: Parental Awareness, The Digital World, Parental Mediation, Reverse Mediation, Teens

\section{Introduction}

The term digital world is used to express the dominance of the use of technology in the modern society - existing, emerging and potential, and this domination includes not only the physical and technical dimension, but also the social dimension as human identity (e-mail address, smart phone number, behavior and interests on social media etc. And the new dimensions of human activities that are conducted digitally, such as the method of human 
communication through education, trade exchange, administration, services, public events, etc., and the effects of these new social phenomena are profound on beliefs, values, customs, traditions and social behaviors, (Ismail, 2019), and it is becoming clear that people who use the services available in the digital world are slowly changing their lifestyle habits and becoming members of the growing information society (Diaz et al., 2020).

By the end of 2019, there are almost more mobile cellular subscriptions than the Earth's population, and $97 \%$ of the world's population lives in areas covered by mobile cellular signals. According to the results of an annual report issued by the social media management platform "Hotsuite" in early 2019, there are about 250 million people in the Middle East, while in Jordan, the number of mobile phone subscriptions is about 8 million, representing $78 \%$ of the population.

But with the tremendous development in the digital environment, the human being has an urgent need to possess basic digital knowledge (media education), that is, to understand and use media messages and information in its various forms from various sources when viewed through computers, and it includes the interpretation of media materials, access to data and images through tools. digital, assess and apply the knowledge gained in their digital business (Diaz et al., 2020). It also includes practices that allow individuals access, and critical evaluation (Potter, 2010). A series of media competencies with the ability to access, analyze, evaluate and communicate in a variety of formats, which can be printed or non-print messages. (Leaning, 2017).

The family first and the school second are responsible for instilling media literacy skills in the younger generation, as what you do deeply affects the children's ability to explore the opportunities of the digital world and avoid its dangers.

For parents, which is the subject of this study, they are it is required to practice effective parental who they are management or mediation between their children and the digital world so that children can safely integrate into the world of today and tomorrow. Strengthening the teaching of the basics of information and media among adolescents requires that parents first be familiar with these basics. Therefore, the initial focus on fathers is a key strategy for providing adolescents with these basics.

Young people are supposed to learn media education from home first, which places a great responsibility on parents. Chiong and Shuler (2010) studies of "Parental Mediation" dealt with the management patterns of fathers to integrate their children into the digital world through many strategies such as authoritarian regulation (restrictive mediation, control and direct supervision) or democratic support (active mediation, remote mediation and participation), (Warren, 2001), and as a result, the goal is to develop children's skills in how to take advantage of the opportunities of the digital world and avoid its harms.

In conclusion, parents should use media education to devote effective parental proactive mediation that does not hinder the integration of their children in the digital world and result in negative reactions, but rather contributes to raising children's awareness, facilitating their 
tasks, enhancing their self-confidence and developing positive self-discipline that stimulates production and organization.

\section{Problem Statement}

Education begins with the family, as it helps in the formation of the child's personality, personality, beliefs and values (Whitbeck, 1999), and the parents take care of the children and teach him his religion, language, concepts of love, custom's, traditions, and behavior. (Blagmas, 2016), before school comes, introduces the child to other races, cultures, religions, and the rules of society (Almagro, 1993). As for the media, it has invaded the field of education, forming the minds, attitudes, feelings and behaviors of young people (Al-Zubaidi \& Al-Obaidi, 2015), and the impasse deepened with the development of this actor, leading to the fast, intractive networked digital also world that is not subject to the logic of space or time. The impact on the new generation has become great (Levin, 2013). The media, in its modern form, has become a factor of confusion for the family and the school, and in view of the power of this factor, society has no choice but to qualify individuals to sort, analyze, criticize and evaluate media and information content before using it. This role is supposed to be played by both the family and the school together, to give the child the ability to research, investigate and think critically and creatively in order to grow in balance and in line with the requirements of the times (Farida, 2016).

There are various parental mediation strategies that are divided into two main axes: either regulating the child's exposure to the digital world through (restrictions, monitoring, and direct supervision) or supporting his self-reliance through (active, participatory and remote mediation). Options, but on the other hand, there is what can be called reverse or harmful mediation, that is, those in which parents do not make any dollars, such as negligence, complete disregard, inconsistent, homogeneous or moody mediation.

Parents bear the responsibility of teaching their children how to deal with the digital world from a young age, but the task is more urgent in the adolescence stage, as children experience mental, physical, psychological and social changes, and they are vulnerable to beliefs, values, ideas, attitudes and behaviors at this stage in which individuals seek independence and are formed during Self-image (Poliquin, 2016). In the opinion of the researcher, and through his contact with adolescent children and their parents, the problem of adolescents' limited exploitation of the opportunities of the digital world in Jordan and their continued exposure to its dangers could be one of the reasons for it that parents practice an adverse or harmful mediation that is manifested in inconsistency or complete indifference. The study is to identify the patterns of reverse parental mediation (harmful) used in Jordan and the extent to which each is practiced to reach a better understanding of the reasons that limit the effectiveness of parental management for their adolescent children in the digital world.

\section{Theoretical Literature}

Communication scholars define "parental mediation", i.e. the management of parents' interactions with their children in relation to the use of devices in the digital world (internet, social media and games, video games, etc.) (Vygotsky, 1986). 
Parental mediation can also be defined as strategies adopted by parents to provide children with the opportunities and risks of the digital world until they become qualified users of it. Or the active role of parents in managing and organizing their children's experiences, or their proactive attempts aimed at enhancing the positive their effects of the digital world and preventing its negative effects on children.

After the Internet, the types of mediation were classified into two directions. The first is organizational and includes restriction, monitoring, and supervision, and the second is supportive, which includes active, remote, explanatory mediation, modeling, trial and error, motivation, family communication, etc., as well as technical methods that use applications and software that true to play the role of parents in mediation and were used in restrictive mediation types. Such as monitoring and restricting access, interaction, or content to which a teenager is exposed. It showed there is inconsistent mediation and a pattern of parents that do not use mediation, that is not at all with the adolescent's behavior in the digital world.

Parental mediation strategies are not always uniform, but there are different types of parental intervention in children's interaction with the digital world, which changes according to the age of the child and the content to which he is exposed (Huovinen, 2007). As it varies by culture, studies have revealed that most Asian children show respect for their parents and obey their instructions. In contrast, children in Western cultures tend to seek autonomy and are more likely to challenge parental authority. Thus, the effectiveness of parental mediation may vary by culture (Hart, 2018).

It goes without saying that parents should be aware of the effect of their mediation style on their children, and they must be aware that it is important that their instructions be consistent in their mediation style, because inconsistent mediation is associated with undesirable outcomes (Jenkins et al., 2009).

Parents are supposed to make efforts to equip children and adolescents in particular with the skills to critically process digital content, i.e. access, deconstruct, sort, analyze and contextualize their production, and then productively employ and reuse them (Ghosh et al., 2020).

The importance of qualifying caregivers in the field of media and information education lies in achieving a balance between the traditional, controlling and restrictive authoritarian role and the modern democratic role that depends on active learning and self-regulation of the child, and avoiding harmful reverse mediation such as indifference or complete disregard or the issuance of conflicting, volatile and incomprehensible temperamental instructions for the child. This often leads to negative results, including depriving children of the opportunity to fully integrate and benefit from sources of information and social communication, or what can be called the new third millennium skills or knowledge age skills, and it increases the risks of losing family trust and transparency (Singh et al., 2017).

\section{Literature Review}

lqbal et al. (2021) conducted a study entitled "Parental mediation predictors of adolescent Internet use" aimed at evaluating the different dimensions of parental mediation regulating 
and predicting adolescent Internet use. A cross-sectional survey was conducted in Lahore district, Pakistan, among adolescent mothers/caregivers (aged 13-19 years). Women were only interviewed because they are more often involved as primary caregivers than fathers or male caregivers. Moreover, only qualified and working mothers from the two highest professions among women, i.e. academia and medicine, were interviewed. A stratified random sampling method was adopted, and 347 mothers were interviewed using face-toface interviews in 11 universities and 11 hospitals/medical colleges. Data were entered and analyzed using descriptive logistic regression, bivariate and multivariate analyses. The results highlighted that more than $65 \%$ of respondents have implemented highly active mediation for Internet security, about $60 \%$ have used highly active mediation in combined use and over $56 \%$ have implemented restricted mediation. In addition, $36 \%$ of participants and $15.3 \%$ were monitored technically to regulate adolescent Internet use. The results of a multivariate logistic regression revealed that the majority of respondents were more likely to adopt active Internet security mediation if they had adolescents aged 16-19 years, with moderate Internet addiction, possessed good digital skills, and felt confident in assessing adolescent coping. To perform online protection.

Steinfeld (2020) conducted a study entitled "Parental mediation of adolescent Internet use: Combining strategies to promote awareness, independence, and self-regulation in preparing young people for life on the Web." The study examines parental mediation strategies for adolescent Internet use and its relationship to adolescent age, online risk concerns, and activities Online, risky behavior. It included a survey of 357 adolescents eudge and its relationship to adolescents age, online risk aged 12-18 and 156 adolescents aged 9-11, and semi-structured interviews with parents, teachers, and adolescents. Typical behavioral, attitudinal, and cognitive aspects of adolescents' Internet use and types of parental mediation were measured. The findings illustrate how parents combine mediation strategies in a variety of formats and contexts. Restricted mediation was associated with increased adolescent fears, indicating an internalization of the risks and consequences of Internet use. However, restrictive mediation was associated with lower Internet activity and increased risk, possibly due to adolescents' lack of experience and desire for independence in dealing with online risks. On the contrary, active mediation is associated with increased Internet activity of any kind, allowing experimentation and independence in Internet use, and is not associated with risks. The study compares mediation strategies with parenting styles and concludes that a balanced mix of restrictive and active mediation would ideally provide the best foundations for adolescents to develop a strong set of norms, boundaries, and the ability to self-regulate their online activities. Which indicates an understanding of the risks and consequences of using the Internet.

Sharqi \& Hezia (2018) conducted a study entitled "The Role of Parents in Media Education for Children on Television". This study sought to identify the role of parents in media education for children on television through a study on a sample of parents in the Wilayat of Bordj Bou Arreridj. The questionnaire was then divided into four main axes, the first axis relates to personal data, the second axis relates to the habits of children's exposure to television from the parents' point of view, and the third axis relates to the extent of parents' awareness of the concept of media education, and the fourth axis is concerned with the regulatory and supervisory role of parents on TV. The study concluded that education on dealing with the 
media is an emerging field related to the processes associated with knowledge of the media and critical analysis of its contents, especially television. Media is a clear modern concept that needs more clarification among parents in the first place to increase their awareness of the role entrusted to them in media education for their children.

Martinez et al (2020) conducted a study entitled "Online Parental Mediation Strategies in Family Contexts in Spain", which aimed to identify online parenting mediation strategies in Spain and their correlation with social, demographic and family context factors. The results of the survey conducted at the end of 2018 are presented here, based on a sample of 2,900 Spanish minors between these ages of 9 and 17 who use the Internet. The effect of various applied parental mediation strategies on Internet use was calculated by taking into account the sociodemographic factors of minor participants (age and gender). Correlation analysis was performed using SPSS statistical analysis software. In this case, an additional analysis was performed regarding the influence relationship between different strategies, rules of behavior and family support in the context of the family as seen by the minor. The results indicate that enabling and constraining mediation strategies are very common in Hispanic families, while technical mediation strategies have a very limited presence. It is worth noting that security restrictions and strategies generally apply to girls more than boys. Family rules regarding the behavior of minors are positively correlated with increased impact of nearly all strategies. However, there is no closely related link between the family support children see and the restrictive strategies and methods that parents apply.

Shaji \& Sebastian (2020), conducted a study entitled "Parental mediation of adolescent Internet use", which aimed to identify the parental mediation of adolescent Internet use in India, and used the descriptive approach to understand the level of parental control over adolescent Internet use in Kerala, India. It also aimed to understand the relationship between various adolescent and parental demographic factors with ease was parental mediation. A stratified sample of parents of 388 students between the ages of 13 and 18 years, drawn from different schools (public, auxiliary and private), was selected. The data was collected through a survey conducted using the parental mediation questionnaire prepared by the researcher, and the study concluded that active mediation was the predominant mediation strategy used by parents more than joint viewing mediation and restrictive mediation. Analysis of adolescent demographics revealed a difference in parental mediation on the Internet use of boys and girls. A difference was also found in the mediation of parents of adolescents attending public, subsidized, and private schools. The study also revealed that younger parents in Kerala mediate more adolescents' internet use than older parents. Other demographic factors related to the parents, including their education, employment status, or annual family income, have little to do with parental mediation. Conclusion, the study identifies the need to sensitize the parental community and provide them with adequate parental mediation support regarding adolescent internet use.

Sorb et al (2020), conducted a study entitled "The role of parental mediation, mental health, high-risk behaviors, and cyberspace activities in Internet addiction: a cross-sectional study", which aims to identify the relationship between parental mediation, mental health, high-risk behaviors and space activities. Cyber addiction in Iranian adolescents, a cross-sectional study that ran from January 10 to June 14, 2019. The sample consisted of 300 secondary students 
aged 14-17 years in Kerman, Iran. Cluster sampling method was used to collect data, and the study concluded that Internet addiction disorder is $51.7 \%$ in adolescents, and that there is a significant negative relationship between maternal function and Internet addiction $(P<0.016)$. The result of the t-test showed that the mediating role of active parental mediation was more in the subjects with Internet addiction and they experienced more online activities, online abuse, substance abuse, and depression, while the role of restrictive mediation, and selfesteem were higher in the subjects Those who do not suffer from Internet addiction, the study concluded that the prevalence of Internet addiction among Iranian adolescents is high, and important factors such as inappropriate parental mediation, psychological vulnerability (such as low self-esteem and depression), high levels of electronic activities, and online abuse are important factors. that cause this disorder.

Zhang \& Zhou (2020), "The relationship between parental online mediation and Internet usage of Chinese children: The role of mediation in personality traits", this study investigated how personality traits mediated the relationship between parental online mediation and Internet use (time and participation) of Chinese children. A sample of 975 children from two Chinese primary schools were asked to report their internet time (daily and weekend), online engagement (information, entertainment and social interaction), parental online mediation, and their personality traits (extroversion and neuroticism). The results indicated the following: 1) Restrictive mediation was negatively associated with children's Internet use time, and the other two dimensions of mediation (active and shared use) were positively associated with children's Internet participation. 2) The extraversion personality mediated the association between the three dimensions of mediation and children's Internet involvement, and the neurotic personality only mediated the relationship between active mediation and time use. The current study highlights the importance of children's personality as a link between the role of parents and children's Internet-related behavior.

Rojas et al (2018), conducted a study entitled "Parental mediation of Internet use in primary school students: Beliefs, strategies, and difficulties", which aimed to analyze daily beliefs, practices, and difficulties faced by parents when try sons and childrens the benefits and risks Internet. The study used the qualitative approach, and the discussion group method was used with four groups of mothers and fathers of primary education students from four educational centers. The results indicate that they share a more pessimistic perception of Internet usage at these ages and that they perceive different difficulties when trying to promote its responsible use. Different parenting mediation strategies have been identified: norm setting, spatiotemporal organization of boundaries, supervision (face-to-face, consensual, nonconsensual and technical) and support (parental modeling, between siblings and different educational strategies, stimulus and family communication), and, with the exception of technical supervision, they usually use it to educate them or controlling their behavior in other areas as part of their overall parenting style. The conclusions point to the need to develop parents' digital competence and some implications for educational intervention such as enhancing cooperation between school and family. Increase motivation and family communication.

Livingstone et al (2017) conducted a study entitled "Maximizing Opportunities and Minimizing Risks for Children Online: The Role of Digital Skills in Emerging Strategies for 
Parental Mediation", which aimed to identify mediation strategies used in the European Union by surveying 6 to 14 years old parents in 8 European countries (number $=6400$ ). The results revealed two parental mediation strategies. Supportive mediation is associated with increased opportunities online but it is also associated with risks. This strategy includes safety efforts, responds to giving children self-responsibility, and is used when a parent or child is relatively digitally savvy. Restrictive mediation is associated with lower risk online but at the expense of opportunity, reflecting the prevailing view that media use is primarily problematic.

Ling \& Yee (2021), a study entitled "Parental Mediation: Its Effect on Affective Behavioral Modification Contexts Among Children in the Kota Kinabalu Region", aimed to study the effect of parental mediation on behavioral-emotional adjustment contexts among 9 to 11 years old In Kota Kinabalu, Sabah. A random sample of 175 parents was recruited to participate in the study using an online Google Forms questionnaire. Multiple regression analysis indicated significance in observing the effect on the context of behavior problems, $F(1,173)=4.666$; hyperactivity, $F(1,173)=13.203 ;$ prosocial behavior, $f(2,172)=13.542 ; p<.05$, with respect to the subscales of the Strengths and Difficulties Questionnaire (SDQ). While active joint use affects peer problem $F(1,173)=7.496$; and prosocial behavior $F(2,172)=13.542, p<.05$. However, interaction and technical limitations did not show any significant effect.

Chen \& Shi (2019) conducted a study entitled "Media Harm Reduction: A Dimensional Analysis of Parental Mediation", which aimed to investigate the effectiveness of parental mediation in media-related harm reduction. Specifically, he examined the magnitude of the usage effects of three major parental mediation strategies on reducing the amount of media use and the incidence of media-related risks. A meta-analysis was performed using 52 pilot studies on parental mediation, which represented a total sample of 74,159 participants and yielded 122 independent associations. The results indicated that restrictive mediation was more effective than active mediation in reducing the amount of time children spent on the media, while the effects of active mediation and co-use were greater than the effect of restrictive mediation on reducing the incidence of media-related risks. According to median analyses, age, type of risk, median.

\section{Methodology}

The research depends on the descriptive analytical approach in dealing with previous studies and the theoretical framework to accurately describe the problem, analyze it and find the relationships between its parties and its interpretation, in an attempt to derive generalizations that lead to the advancement of knowledge, and to develop appropriate solutions to the problem under study. (Awad et al., 2002). Studied community it includes parents of teenagers from 13 to 17 years old who reside on the territory of the Hashemite Kingdom of Jordan and whose number is 614413 (Statistical Report for the academic year 2018/2019, Ministry of Education), and therefore the number of fathers for this group is estimated at about one million and two hundred thousand citizens (assuming that each teenager has father and mother).

The sample: First the exploratory study sample. The exploratory study sample consisted of (30) individuals (father and mother), with the aim of ensuring the validity and reliability of the study tools, and their suitability for the sample members. Second: The main study sample: 
DEVELOPMENT

Vol. 10, No. 3, 2021, E-ISSN: 2226-6348 @ 2021 HRMARS

consisting of (469) singles (father or mother) residing in the Hashemite Kingdom of Jordan were selected in an intentional (non-probability) manner, about half of them are males and the other half are females, the study took into account the ability of the respondents to deal with google forms, (Abbas et al., 2012) defined the intentional sample as that whose units are selected according to criteria set by the researcher without being bound by the laws of probability. The scale of the use of parents of adolescents in Jordan for patterns of harmful reverse mediation in managing the integration of their children in the digital world prepared by the researcher was applied to the sample.

Descriptive Analysis of Demographic Variables for The Studied Sample.

Table1) Descriptive analysis of demographic variables for the study sample

\begin{tabular}{|c|c|c|c|c|c|c|c|c|c|c|c|}
\hline \multicolumn{3}{|l|}{ sex } & \multicolumn{3}{|l|}{ Age } & \multicolumn{3}{|c|}{ Educational level } & \multicolumn{3}{|c|}{ income level } \\
\hline $\begin{array}{l}\text { Relati } \\
\text { onshi } \\
p\end{array}$ & $\begin{array}{l}\text { Rep } \\
\text { etiti } \\
\text { on }\end{array}$ & $\begin{array}{l}\text { Th } \\
\text { e } \\
\text { rat } \\
\text { io }\end{array}$ & Age & $\begin{array}{l}\text { Rep } \\
\text { etiti } \\
\text { on }\end{array}$ & $\begin{array}{l}\text { Th } \\
\text { e } \\
\text { rat } \\
\text { io }\end{array}$ & $\begin{array}{l}\text { educatio } \\
\mathrm{n}\end{array}$ & $\begin{array}{l}\text { Rep } \\
\text { etiti } \\
\text { on }\end{array}$ & $\begin{array}{l}\text { Th } \\
\text { e } \\
\text { rat } \\
\text { io }\end{array}$ & income & $\begin{array}{l}\text { Rep } \\
\text { etiti } \\
\text { on }\end{array}$ & $\begin{array}{l}\text { Th } \\
\text { e } \\
\text { rat } \\
\text { io }\end{array}$ \\
\hline dad & 221 & $\begin{array}{l}47 \\
.1 \\
\%\end{array}$ & $\begin{array}{l}\text { Less tha } \\
\text { n } 40 \text { yea } \\
\text { rs old }\end{array}$ & 118 & $\begin{array}{l}25 \\
2 . \\
\%\end{array}$ & $\begin{array}{l}\text { Less tha } \\
\mathrm{n} \\
\text { a second } \\
\text { ary publi } \\
\text { c }\end{array}$ & 46 & $\begin{array}{l}9 . \\
8 \\
\%\end{array}$ & $\begin{array}{l}\text { Less than } \\
\text { 400dinars }\end{array}$ & 111 & $\begin{array}{l}23 \\
7 . \\
\%\end{array}$ \\
\hline $\begin{array}{l}\text { Moth } \\
\text { er }\end{array}$ & 248 & $\begin{array}{l}52 \\
.9 \\
\% \\
\end{array}$ & $\begin{array}{l}41 \quad- \\
50 \text { year }\end{array}$ & 167 & $\begin{array}{l}35 \\
6 . \\
\% \\
\end{array}$ & $\begin{array}{l}\text { commun } \\
\text { ity colleg } \\
\text { e }\end{array}$ & 107 & $\begin{array}{l}22 \\
8 . \\
\% \\
\end{array}$ & $\begin{array}{l}400 \quad- \\
1000 \text { Dina } \\
r\end{array}$ & 236 & $\begin{array}{l}50 \\
3 . \\
\%\end{array}$ \\
\hline & & & $\begin{array}{l}51 \\
60 \text { year }\end{array}$ & 143 & $\begin{array}{l}30 \\
5 . \\
\%\end{array}$ & $\begin{array}{l}\text { Bachelor } \\
\text { 's }\end{array}$ & 222 & $\begin{array}{l}47 \\
3 . \\
\%\end{array}$ & $\begin{array}{l}\text { More than } \\
1000 \text { dina } \\
\text { rs }\end{array}$ & 122 & $\begin{array}{l}26 \\
0 . \\
\%\end{array}$ \\
\hline & & & $\begin{array}{l}\text { More th } \\
\text { an } 60 \text { ye } \\
\text { ars }\end{array}$ & 41 & $\begin{array}{l}8 . \\
7 \\
\% \\
\end{array}$ & $\begin{array}{l}\text { Studies } \\
\text { graduat } \\
\text { e }\end{array}$ & & 94 & & & \\
\hline Total & 469 & $\begin{array}{l}10 \\
0 \\
\%\end{array}$ & Total & 469 & $\begin{array}{l}10 \\
0 \\
\%\end{array}$ & Total & 469 & $\begin{array}{l}10 \\
0 \\
\%\end{array}$ & Total & 469 & $\begin{array}{l}10 \\
0 \\
\%\end{array}$ \\
\hline
\end{tabular}

Prepared by the researcher based on the data included in Appendix No. (---) using software SPSS

\section{Study Tool}

After reviewing the researcher's educational literature and previous studies that dealt with the issue of fathers' mediation for their adolescent children in the digital world, and similar measures, especially those derived from the European Union's comprehensive survey Global Kids Onlinelssue 2020, he prepared a scale of use of parents of adolescents in Jordan to patterns of harmful inverse mediation in the digital world, and formulated procedural definitions of: the digital world, parental mediation, inconsistent mediation, indifference, and complete prevention, and identified the main axes of the scale, which included: three axes, 5 incongruent clauses, 5 omission clauses, and 5 outright bans, 
Thus, the scale included 15 items, and the questionnaire was corrected on a five-point Likert scale froml to 5

Table (2) Evaluation of Averages

\begin{tabular}{|l|l|l|}
\hline $\begin{array}{l}\text { the } \\
\text { number }\end{array}$ & percentage & Evaluation \\
\hline 1 & $\%(20-1)$ & Strongly Disagree \\
\hline 2 & $\%(40-21)$ & not agree \\
\hline 3 & $\%(60-41)$ & neutral \\
\hline 4 & $\%(80-61)$ & Agree \\
\hline 5 & $\%(\% 100-81)$ & Strongly Agree \\
\hline
\end{tabular}

Has been confirmed sincerity of the scale through display its scale preliminary 1 as orally 0 arbitrator yen where they by making their views and noting concern about the appropriate areas, and the extent of affiliation paragraphs to each axis of the three axes, and after reviewing the views and observations of the arbitrators resulted in arbitration results for access Most of the areas on the degree of agreement between the arbitrators reached $80 . \%$ The criterion of the agreement of seven arbitrators was based on the validity and clarity of the paragraph to remain within the instrument, or on the agreement of three arbitrators that it was not clear to amend it and the scale has been modified in light of the arbitrators' written or oral observations, and accordingly it can be said that the scale is appropriate and valid.

As for the internal consistency, the validity of the internal consistency of the study tool was verified by calculating the correlation coefficient) Pearson Correlation in the exploratory sample consisting of (30) singles that were not included in the basic sample, and the correlation between the phrase and the dimension to which it belongs, and the tool as a whole was calculated, as shown in the tables (3) below.

Table (3) Correlation coefficients for parents 'use of total prevention patterns

\begin{tabular}{|c|l|l|r|l|l|r|l|l|}
\hline $\begin{array}{l}\text { Mediation is inconsistent( non } \\
\text {-organization or mood ) }\end{array}$ & \multicolumn{2}{l|}{ Neglect (indifference) } & \multicolumn{2}{l|}{ complete ban } \\
\hline 1 & $0.795^{* *}$ & $\begin{array}{l}0.612^{*} \\
*\end{array}$ & 1 & $\begin{array}{l}0.535^{*} \\
*\end{array}$ & $\begin{array}{l}0.441^{*} \\
*\end{array}$ & $\begin{array}{l}0.808^{*} \\
*\end{array}$ & $\begin{array}{l}0.245^{*} \\
*\end{array}$ \\
\hline 2 & $0.549^{* *}$ & $\begin{array}{l}0.323^{*} \\
*\end{array}$ & 2 & $\begin{array}{l}0.801^{*} \\
*\end{array}$ & $\begin{array}{l}0.603^{*} \\
*\end{array}$ & 2 & $\begin{array}{l}0.744^{*} \\
*\end{array}$ & $\begin{array}{l}0.231^{*} \\
*\end{array}$ \\
\hline 3 & $0.740^{* *}$ & $\begin{array}{l}0.486^{*} \\
*\end{array}$ & 3 & $\begin{array}{l}0.875^{*} \\
*\end{array}$ & $\begin{array}{l}0.619^{*} \\
*\end{array}$ & 3 & $\begin{array}{l}0.737^{*} \\
*\end{array}$ & $\begin{array}{l}0.270^{*} \\
*\end{array}$ \\
\hline 4 & $0.761^{* *}$ & $\begin{array}{l}0.569^{*} \\
*\end{array}$ & 4 & $\begin{array}{l}0.610^{*} \\
*\end{array}$ & $\begin{array}{l}0.454^{*} \\
*\end{array}$ & 4 & $\begin{array}{l}0.677^{*} \\
*\end{array}$ & $\begin{array}{l}0.319^{*} \\
*\end{array}$ \\
\hline 5 & $0.671^{* *}$ & $\begin{array}{l}0.412^{*} \\
*\end{array}$ & 5 & $\begin{array}{l}0.745^{*} \\
*\end{array}$ & $\begin{array}{l}0.527^{*} \\
*\end{array}$ & 5 & $\begin{array}{l}0.766^{*} \\
*\end{array}$ & $\begin{array}{l}0.329^{*} \\
*\end{array}$ \\
\hline
\end{tabular}


DEVELOPMENT

Vol. 10, No. 3, 2021, E-ISSN: 2226-6348 @ 2021 HRMARS

It is clear from the above tables that all correlation coefficients were statistically significant, whether between the phrase and the dimension to which it belongs, or between the phrase and the tool as a whole, which indicates the internal consistency between the statements and that they are structurally valid and applicable.

The measure of the stability of $\mathrm{P}$ has been stable account of by calculating the coefficient Cronbach alpha) Chronbach Alpha (as shown in Tables (4) below. Where it is clear that all values of Cronbach's alpha coefficient were greater than $(0.70)$, which indicates the stability quality of the research tools.

Table (4) Cronbach's alpha coefficient

\begin{tabular}{|l|l|l|l|}
\hline & variable & $\begin{array}{l}\text { number of } \\
\text { paragraphs }\end{array}$ & $\begin{array}{l}\text { Cronbach's } \\
\text { alpha } \\
\text { coefficient }\end{array}$ \\
\hline 1. & $\begin{array}{l}\text { Inconsistent mediation (disorganized or } \\
\text { moody( }\end{array}$ & 5 & 0.760 \\
\hline 2. & negligence (indifference( & 5 & 0.745 \\
\hline 3. & complete ban & 5 & 0.795 \\
\hline & Total & 15 th & 0.705 \\
\hline
\end{tabular}

Prepared by the researcher based on the data included in Appendix No ( --- ) . using softwareSPSS

\section{Result}

In order to analyze the questionnaire items, the arithmetic averages and standard deviations were calculated for each item .The averages were evaluated as follows:

Table (5) Evaluation of Averages

\begin{tabular}{|l|l|}
\hline SMA & Evaluation \\
\hline $1.80-1$ & A little bit \\
\hline $2.60-1.80$ & Little \\
\hline $3.40-2.60$ & middle \\
\hline $4.20-3.40$ & Many \\
\hline $5.00-4.20$ & too much \\
\hline
\end{tabular}

To answer the question of the research, which states, "To what extent do parents of adolescents in Jordan use patterns of reverse parental mediation (harmful) in the digital world? ", was answered by extracting the arithmetic means and standard deviations of the answers of the study sample members on the scale of the use of fathers of adolescents in Jordan to patterns of reverse parental mediation (harmful) in the digital world for each of the inconsistent mediation (moodiness), complete neglect (apathy), complete prevention and the axis of Reverse (harmful) mediation as a whole. 
INTERNATIONAL JOURNAL OF ACADEMIC RESEARCH IN PROGRESSIVE EDUCATION AND

DEVELOPMENT

Vol. 10, No. 3, 2021, E-ISSN: $2226-6348$ @ 2021 HRMARS

\section{Inconsistent Mediation (Disorganized or Moody)}

Table (6) shows the frequencies, mean, standard deviation, rank, and rating for inconsistent mediation disorganized or moody).

\begin{tabular}{|c|c|c|c|c|c|c|c|c|c|c|c|}
\hline & Unfair Mediation & 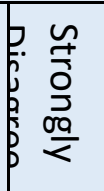 & 点 & 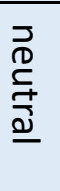 & 읏 & 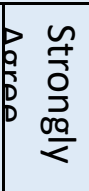 & $\begin{array}{l}-1 \\
\stackrel{O}{+} \\
\underline{D}\end{array}$ & 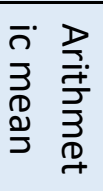 & 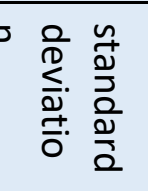 & & 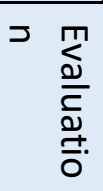 \\
\hline 1. & $\begin{array}{l}\text { Use the method is fixed or } \\
\text { entrepreneur in } \\
\text { the administration exposed my } \\
\text { son to devices digital }\end{array}$ & 46 & 237 & $\begin{array}{l}5 \\
2\end{array}$ & $\begin{array}{l}8 \\
1\end{array}$ & 53 & 469 & 2.70 & 1.197 & 3 & $\begin{array}{l}\text { midd } \\
\text { le }\end{array}$ \\
\hline 2. & $\begin{array}{l}\text { Rely on direct reactions in } \\
\text { managing my son's integration } \\
\text { on the Internet }\end{array}$ & 35 & 228 & $\begin{array}{l}7 \\
1\end{array}$ & $\begin{array}{l}9 \\
5\end{array}$ & 40 & 469 & 2.74 & 1.124 & 2 & $\begin{array}{l}\text { midd } \\
\text { le }\end{array}$ \\
\hline$\beta$. & $\begin{array}{l}\text { I allow } \quad \text { my son to } \\
\text { bypass instructions for using } \\
\text { digital devices when I'm busy }\end{array}$ & 67 & 166 & $\begin{array}{l}9 \\
0\end{array}$ & $\begin{array}{l}9 \\
4\end{array}$ & 52 & 469 & 2.78 & 1.235 & 1 & $\begin{array}{l}\text { midd } \\
\text { le }\end{array}$ \\
\hline 4. & $\begin{array}{l}\text { I } \\
\text { set instructions but it is often vi } \\
\text { olated by } \\
\text { the partner ) mother if the resp } \\
\text { ondent is a father } \\
\text { and vice versa ( } \\
\text { "There is no agreement betwe } \\
\text { en the parents" }\end{array}$ & 72 & 195 & $\begin{array}{l}9 \\
6\end{array}$ & $\begin{array}{l}8 \\
2\end{array}$ & 24 & 469 & 2.55 & 1.102 & 5 & Little \\
\hline 5. & $\begin{array}{l}\text { I allow my son to violate } \\
\text { the agreed upon in his } \\
\text { interaction with digital devices } \\
\text { when visiting or receiving relati } \\
\text { ves or friends }\end{array}$ & 43 & 229 & $\begin{array}{l}6 \\
7\end{array}$ & $\begin{array}{l}8 \\
4\end{array}$ & 46 & 469 & 2.70 & 1.158 & 3 & $\begin{array}{l}\text { midd } \\
\text { le }\end{array}$ \\
\hline & $\begin{array}{l}\text { Mediation is inconsistent ) non } \\
\text {-organized Ooualem'zajih ( as } \\
\text { a whole }\end{array}$ & & & & & & & $\begin{array}{l}2.69 \\
51\end{array}$ & $\begin{array}{l}0.8314 \\
8\end{array}$ & & $\begin{array}{l}\text { midd } \\
\text { le }\end{array}$ \\
\hline
\end{tabular}

Prepared by the researcher based on the data of the study using software SPSS 
INTERNATIONAL JOURNAL OF ACADEMIC RESEARCH IN PROGRESSIVE EDUCATION AND

DEVELOPMENT

Vol. 10, No. 3, 2021, E-ISSN: 2226-6348 @ 2021 HRMARS

\section{Total Negligence}

The table shows (7) frequencie center arithmetic and the deviation of the standard grade and evaluation for negligence (indifference)

Table (7) center arithmetic and deviation standard completely ignored

\begin{tabular}{|c|c|c|c|c|c|c|c|c|c|c|}
\hline carelessness & 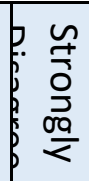 & כָ & $\begin{array}{l}\vec{D} \\
\stackrel{D}{+} \\
\stackrel{+}{+} \\
\underline{\underline{D}}\end{array}$ & 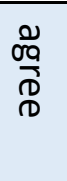 & $\begin{array}{l}\stackrel{n}{+} \\
\stackrel{0}{0} \\
\stackrel{0}{\alpha} \\
\stackrel{o a}{<}\end{array}$ & $\begin{array}{l}-1 \\
\underline{O} \\
\underline{\underline{O}}\end{array}$ & 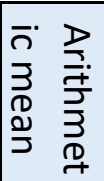 & 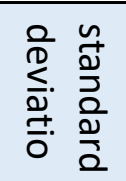 & 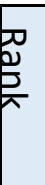 & 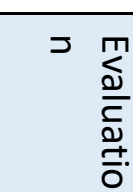 \\
\hline $\begin{array}{l}\text { do not interfere with wha } \\
\text { t my } \\
\text { son does or follows in the } \\
\text { digital world because he } \\
\text { is technically superior } \\
\text { to me }\end{array}$ & 29 & $\begin{array}{l}15 \\
2\end{array}$ & $\begin{array}{l}15 \\
7\end{array}$ & 97 & 34 & $\begin{array}{l}46 \\
9\end{array}$ & 2.90 & 1.030 & 1 & middle \\
\hline $\begin{array}{l}\text { I } \\
\text { do n't interfere with what } \\
\text { my } \\
\text { son does or follows in the } \\
\text { digital world because I d } \\
\text { on't know what's right }\end{array}$ & 54 & $\begin{array}{l}15 \\
3\end{array}$ & $\begin{array}{l}13 \\
2\end{array}$ & $\begin{array}{l}12 \\
6\end{array}$ & 4 & $\begin{array}{l}46 \\
9\end{array}$ & 2.73 & 1.009 & 5 & middle \\
\hline $\begin{array}{l}\text { do not interfere with wha } \\
\text { t my } \\
\text { son does or follows in the } \\
\text { digital world because of } \\
\text { the failure } \\
\text { of my previous interventi } \\
\text { ons }\end{array}$ & 37 & $\begin{array}{l}16 \\
4\end{array}$ & $\begin{array}{l}14 \\
4\end{array}$ & 90 & 34 & $\begin{array}{l}46 \\
9\end{array}$ & 2.83 & 1.058 & 3 & middle \\
\hline $\begin{array}{l}\text { I } \\
\text { do n't interfere with what } \\
\text { my } \\
\text { son does or follows in the } \\
\text { digital world because of } \\
\text { his busyness }\end{array}$ & 27 & $\begin{array}{l}17 \\
6\end{array}$ & $\begin{array}{l}13 \\
1\end{array}$ & $\begin{array}{l}10 \\
1\end{array}$ & 34 & $\begin{array}{l}46 \\
9\end{array}$ & 2.87 & 1.047 & 2 & middle \\
\hline $\begin{array}{l}\text { Do } \\
\text { not interfere with doing o } \\
r \text { watched my son in } \\
\text { the world digital This is } \\
\text { an important school }\end{array}$ & 49 & $\begin{array}{l}17 \\
6\end{array}$ & $\begin{array}{l}10 \\
9\end{array}$ & $\begin{array}{l}11 \\
1\end{array}$ & 24 & $\begin{array}{l}46 \\
9\end{array}$ & 2.75 & 1.085 & 4 & middle \\
\hline $\begin{array}{l}\text { Neglect ( indifference) as } \\
\text { a whole }\end{array}$ & & & & & & & $\begin{array}{l}2.81 \\
75\end{array}$ & $\begin{array}{l}0.736 \\
32\end{array}$ & & middle \\
\hline
\end{tabular}

Prepared by the researcher based on the data of the study using software SPSS 
INTERNATIONAL JOURNAL OF ACADEMIC RESEARCH IN PROGRESSIVE EDUCATION AND

DEVELOPMENT

Vol. 10, No. 3, 2021, E-ISSN: 2226-6348 @ 2021 HRMARS

\section{Complete Band}

Table (8) shows the frequencies, mean, standard deviation, rank, and rating for the mediation of complete prevention.

Table (8) center arithmetic and deviation standard completely ignored

\begin{tabular}{|c|c|c|c|c|c|c|c|c|c|c|}
\hline complete ban & 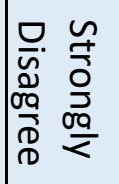 & 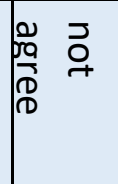 & $\begin{array}{l}\vec{J} \\
\mathbb{D} \\
\stackrel{+}{+} \\
\stackrel{+}{0} \\
\underline{D}\end{array}$ & 荡 & 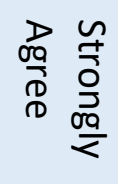 & $\begin{array}{l}-1 \\
\stackrel{O}{\Phi} \\
\underline{D}\end{array}$ & 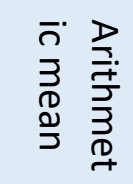 & $\begin{array}{l}\frac{0}{0} \\
\frac{n}{10} \\
\frac{0}{0} \\
\frac{0}{0} \\
\frac{0}{0} \\
\frac{0}{2}\end{array}$ & $\begin{array}{l}\text { ग्ग } \\
\text { 귯 }\end{array}$ & 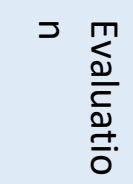 \\
\hline $\begin{array}{l}\text { Forbid my son to } \\
\text { use the } \\
\text { smartphone }\end{array}$ & 188 & 232 & 44 & 4 & 1 & $\begin{array}{l}46 \\
9\end{array}$ & 1.72 & 0.685 & 5 & $\begin{array}{l}\text { A little } \\
\text { bit }\end{array}$ \\
\hline $\begin{array}{l}\text { Prevent my son } \\
\text { from accessing } \\
\text { the internet }\end{array}$ & 186 & 218 & 51 & $\begin{array}{l}1 \\
0\end{array}$ & 4 & $\begin{array}{l}46 \\
9\end{array}$ & 1.78 & 0.788 & 4 & $\begin{array}{l}\text { A little } \\
\text { bit }\end{array}$ \\
\hline $\begin{array}{l}\text { I forbid my son } \\
\text { to have social } \\
\text { media accounts }\end{array}$ & 185 & 203 & 68 & $\begin{array}{l}1 \\
0\end{array}$ & 3 & $\begin{array}{l}46 \\
9\end{array}$ & 1.81 & 0.805 & 3 & Little \\
\hline $\begin{array}{l}\text { I forbid my son } \\
\text { to play any kind } \\
\text { of digital games }\end{array}$ & 156 & 206 & 78 & $\begin{array}{l}2 \\
9\end{array}$ & 0 & $\begin{array}{l}46 \\
9\end{array}$ & 1.96 & 0.864 & 1 & Little \\
\hline $\begin{array}{l}\text { I forbid my son } \\
\text { to have an email }\end{array}$ & 153 & 235 & 70 & 9 & 2 & $\begin{array}{l}46 \\
9\end{array}$ & 1.87 & 0.759 & 2 & Little \\
\hline \multicolumn{7}{|l|}{ Total ban } & 1.8281 & $\begin{array}{l}0.579 \\
77\end{array}$ & & Little \\
\hline
\end{tabular}

Prepared by the researcher based on the data of the study using software SPSS

\section{The axis of reverse (harmful) mediation as a whole}

The table shows (9) the arithmetic mean and standard deviation of the axis of the mediation reverse (harmful (as a whole

Table (9) arithmetic mean and standard deviation of the inverse (harmful (mediation axis as a whole

\begin{tabular}{|l|l|l|l|}
\hline The reverse ) harmful ( mediation axis as & $\begin{array}{l}\text { Arithmetic } \\
\text { a whole }\end{array}$ & $\begin{array}{l}\text { standard } \\
\text { deviation }\end{array}$ & Evaluation \\
\cline { 2 - 4 } & 2.4469 & 0.44579 & Little \\
\hline
\end{tabular}

Prepared by the researcher based on the data included in Appendix

No. (---) using software SPSS

\section{Discussion}

In the answer to the question of the research, we found the fathers use the reverse mediation with an arithmetic average ( 2.45 out of 5$)$, and although the evaluation is considered low, this indicates the existence of such patterns in Jordanian society, which is a worrying matter, as little in this case does not reflect the marginality of these practices, especially that the numbers are close to the average rating score.

The enormity of the matter becomes apparent if we review the patterns under study: 


\section{First: Inconsistent Mediation (Moods)}

The results showed that (2.69 out of 5 ) of the sample members practice temperamental parental mediation, that is, more than half of the fathers practice irregular and fluctuating mediation, and it appears in the results that the paragraph "I allow my son to bypass instructions for using digital devices when I am busy," which can be explained That parents use organizational mediation strategies, but they do not follow up on their implementation, which loses their effectiveness, and this confirms that the paragraph "I depend on direct reactions in managing my son's integration with the Internet" came in second place, while the paragraph "I set instructions but often violated by the partner" "The last rank, and this cannot be explained by the fact that the parents agree to the extent that there is an authorization most of the time from the father to the mother to exercise the role of mediation, but although this parental behavior is at the bottom of the order in this dimension, it is present and to a medium degree also in all the paragraphs of this dimension. The result is consistent with and the previous result is also consistent with the findings of some previous studies that examined patterns of parental mediation in the digital world, such as Ling and Yee (2021) and Steinfeld (2020) study.

\section{Second: Complete Disregard (Indifference)}

This is a very dangerous aspect as well, as the results revealed that ( 2.82 out of 5 ) of the sample members do not practice any kind of parental management for the integration of their teenage children into the digital world, and the results show that the paragraph "I do not interfere with what my son does or follows in the digital world because of His superiority over me technically", came first, which clearly indicates the parents' recognition of the existence of a gap in digital knowledge between them and their children, a fact that is proven by many studies, including the study of Singh et al (2017), but does not justify parents abandoning the role of mediation, followed by the paragraph "I do not interfere with what my son does or follows in the digital world because of busyness," which is consistent with the result in the first dimension (mood mediation), which showed that preoccupation is the first factor that takes the lead in justifying parents for practicing reverse mediation, and ranked he last paragraph is "I do not interfere with what my son does or follows in the digital world because I do not know what is right." Although this paragraph appends this dimension, it indicates that parents acknowledge their need for awareness or training in this field, and the result is consistent with what the study concluded Rojas et al (2018) found weakness in family communication, and recommended increased motivation and communication to seize opportunities and reduce risks. It also agrees with the findings of a study by Vismara et al (2017), which concluded that there is a need for parental guidance and education for the sound development of the child at this critical stage (adolescence).

\section{Third: Complete Band}

The result in this dimension was low (1.83 out of 5), but it has deep implications, as there is a significant percentage of parents of teenagers who still believe in the idea of isolating adolescents from their digital environment or quarantining them from what is happening in the world of today and tomorrow. Smartphone", and "I prevent my son from connecting to the Internet", in the last two ranks and with a very low rating, but this means that there are parents who do not realize the consequences of preventing their children from integrating into the digital world and consequently they are left behind and lose the vast and important 
opportunities of this world for the continuity. It is also remarkable that the results highlight that the paragraph "I prevent my son from playing any kind of digital games" came in the first place, which can be explained by the fact that parents' evaluation of their children's practice of digital games is negative regardless of the difference content of these games and ignoring that playing in this Age is a basic need that must be met. The result is in agreement with the study by (Livingstone et al., 2017).

In general, it seems that the adverse mediation as a whole took a low assessment because the assessment of the third type (complete prevention) took a low assessment, while the irregular mediation and indifference took an average assessment, which affected the result and made it move from a medium to a low level.

\section{Recommendations and Suggestions}

Increasing the awareness of parents in the Jordanian society about the opportunities and risks of the digital world and the importance of their role in integrating their children in it, which deserves attention. Adopting systematic training to increase parents' awareness of the opportunities and risks of the digital world and the patterns of managing their children on it. Urging the Ministry of Education to pay great attention to media education through the curricula independently and within all other knowledge disciplines, and to adopt the awareness of students' parents about it. Urging civil society organizations, including child protection and defense organizations, to adopt the training of fathers in the fields of parental mediation in the digital world in order to obtain their right to invest in opportunities and prevent risks.

\section{References}

Diaz, G. A., Reig, R., \& Chavez, R. M. (2020). Curriculo de Alfabetizacion Mediatica e Informacional de la UNESCO para profesores desde la perspectiva de la Estructura de la Información. Comunicar: Revista Científica de Comunicación y Educación, 28(62), 103114.

Leaning, M. (2017). Media and information Literacy: An Integrated Approach for the 21st Century. Chandos Publishing.

Chiong, C., \& Shuler, C. (2010). Learning: Is There an App for that. In Investigations of Young Children's Usage and Learning with Mobile Devices and Apps. New York: The Joan Ganz Cooney Center at Sesame Workshop (pp. 13-20).

Al-Zubaidi, Majid, I. A., Al-Obaidi, Salt, A. (2015). The Problem of Family Education and the Challenges of the New Media: A Survey Study on a Sample of Parents in the City of Kirkuk. Communication and Development, 128(2549), 1-29.

Plagmas, B. (2016). The Communicative and Technological Dimension of Globalization and Its Impact on Social Relations: The Algerian Family as a Model.

Farida, A. I. (2016). Media Education and Participatory Culture = Le Média Éducation et la Culture Participative. Majallat al-Turāth, 46(4038), 1-10.

Rojas, I. B., Barandiaran, A. A., \& González, E. O. (2018). Mediación parental del uso de Internet en el alumnado de Primaria: creencias, estrategias y dificultades. Comunicar, 26(54), 71-79. 
Ghosh, A. K., Hughes, C. E., \& Wisniewski, P. J. (2020). Circle of Trust: A New Approach to Mobile Online Safety for Families. In Proceedings of the $2020 \mathrm{CHI}$ Conference on Human Factors in Computing Systems (pp. 1-14).

Hart, A. (2018). Textual Pleasures and Moral Dilemmas: Teaching Media Literacy in England. In Media Literacy Around the World (pp. 199-211). Routledge.

Huovinen, S. (2007). Lapsille haitallisten pelien valvonta on liian hajanaista. HelsinginSanomat 17.2.

Hassan, S. A., \& Khairuldin, W. M. K. F. W. (2020). Research Design Based on Fatwa Making Process: An Exploratory Study. International Journal of Higher Education, 9(6), 241-246.

Said, N. A., \& Khairuldin. (2017). Freedom of Speech in Islam and its Connection with Street Demonstrations. International Journal of Academic Research in Business and Social Sciences, 7(4), 122-129.

Khairuldin, Embong, A. H., Anas, W. N. I. W. N., Ismail, D., Ibrahim, I., \& Fauzi, N. (2017). Freedom of Speech: A Comparative Study between Islam and Malaysian Laws. International Journal of Academic Research in Business and Social Sciences, 7(2), 22226990.

Ibrahim, I., \& Khairuldin. (2017). Fatwa as a Medium Da'wah: Studies on the Role of Mufti as a Preacher. International Journal of Academic Research in Business and Social Sciences, 7(4), 10-18.

Iqbal, S., Zakar, R., \& Fischer, F. (2021). Predictors of Parental Mediation in Teenagers' Internet Use: A Cross-sectional Study of Female Caregivers in Lahore, Pakistan. BMC Public Health, 21(1), 1-14.

Jenkins, H., Purushotma, R., Weigel, M., Clinton, K., \& Robison, A. J. (2009). Confronting the Challenges of Participatory Culture: Media Education for the 21st Century. Mit Press.

Sharqi \& Hezia. (2018). "The Role of Parents in Media Education for Children on Television" (Doctoral Dissertation, Faculty of Humanities and Social Sciences, Mohamed Boudiaf University in M'sila).

Levin, D. E. (2013). Moving Beyond Remote-controlled Teaching and Learning. [Diane E. Levin's Blog on Raising Healthy Kids in a Mad World]. Retrieved from http://dianeelevin.com/2013/moving-beyond-remote-controlled-teaching-andlearning/.

Ling, C., \& Yee, H. K. (2021). Parental Mediation: Its Impact on Contexts of Emotional Behavioral Adjustment among Children in Kota Kinabalu District. Cogent Social Sciences, 7(1), 1870070.

Livingstone, S., Olafsson, K., Helsper, E. J., Villanueva, F. L., Veltri, G. A., \& Folkvord, F. (2017). Maximizing Opportunities and Minimizing Risks for Children Online: The Role of Digital Skills in Emerging Strategies of Parental Mediation. Journal of Communication, 67(1), 82-105.

Martinez, G., Casado, M. A., \& Garitaonandia, C. (2020). Online Parental Mediation Strategies in Family Contexts of Spain. Comunicar, 28(65), 67-76.

Poliquin, A. (2016). Media Literacy Education: A Media Literacy Campaign on the Social Significance of Media Literacy and Its Educational Need. ProQuest LLC.

Shaji, M., \& Sebastian, T. (2020). Parental Mediation of Adolescents' Internet Use. International Journal of Behavioral Sciences, 14(3), 131-135. 
Singh, M. M., Amiri, M., \& Sabbarwal, S. (2017). Social Media Usage: Positive and Negative Effects on the Lifestyle of Indian Youth. Iranian Journal of Social Sciences and Humanities Research, 5(3).

Sorbi, M. H., Dasteaee, S. M., \& Koohestani, F. (2020). The Role of Parental Mediation, Mental Health, High-Risk Behaviors, and Cyberspace Activities in Internet Addiction: A CrossSectional Study.

Steinfeld, N. (2020). Parental Mediation of Adolescent Internet Use: Combining Strategies to Promote Awareness, Autonomy and Self-regulation in Preparing Youth for Life on the Web. Education and Information Technologies, 1-24.

Vismara, M. F. M., Toaff, J., Pulvirenti, G., Settanni, C., Colao, E., Lavano, S. M., \& Marotta, R. (2017). Internet Use and Access, Behavior, Cyberbullying, and Grooming: Results of an Investigative Whole City Survey of Adolescents. Interactive Journal of Medical Research, 6(2), E6231.

Vygotsky L. S. (1986). Thought and Language. Cambridge: MIT Press.

Warren, R. (2001). In Words and Deeds: Parental Involvement and Mediation of Children's Television Viewing. The Journal of Family Communication, 1(4), 211-231.

Whitbeck, L. B. (1999). Primary Socialization Theory: It All Begins with the Family. Substance Use \& Misuse, 34(7), 1025-1032.

Zhang, D. J., Na, W. U., \& Zhou, Z. K. (2020). The Relationship between Parental Internet Mediation and Internet Usage of Chinese Children: The Mediation Role of Personality Trait. DEStech Transactions on Social Science, Education and Human Science, (eels).

Almagro, I. G. (1993). Socialization: An Interactive Process. RS, Cuadernos de Realidades Sociales (41-42), 227-246.

Potter, W. J. (2010). The State of Media Literacy. Journal of Broadcasting \& Electronic Media. 54 (4), 675-696. 